\title{
Methane-derived stromatolitic carbonate crust from an active fluid seepage in the western basin of the Sea of Marmara: mineralogical, isotopic and molecular geochemical characterization
}

\author{
Akhoudas C. ${ }^{1}$, Chevalier N. ${ }^{1,}$, Blanc-Valleron M-M ${ }^{2}$, Klein V. ${ }^{1}$, Mendez-Millan M. ${ }^{3}$, Demange J. ${ }^{1}$, \\ Dalliah S. ${ }^{2}$, Rommevaux V. ${ }^{2}$, Boudouma O. ${ }^{2}$, Pierre C. ${ }^{1}$, Ruffine Livio ${ }^{4}$
}

${ }^{1}$ Sorbonne Universités, UPMC, CNRS, IRD, MNHN, IPSL, LOCEAN, Paris, France

${ }^{2}$ Sorbonne Universités, MNHN, UPMC, CNRS, CR2P, Paris, France

${ }^{3}$ Sorbonne Universités, IRD, UPMC, CNRS, MNHN, IPSL, LOCEAN, Bondy, France

${ }^{4}$ IFREMER, Département REM, Unité des Géosciences Marines, Plouzané, France

* Corresponding author : N. Chevalier, email address : nicolas.chevalier@upmc.fr

\begin{abstract}
:
Cold seeps along the North Anatolian fault in the Sea of Marmara (Turkey) were explored during submersible dives of the Marsite cruise in November 2014 when sediments, pore waters and carbonate crusts were sampled at active fluid seeping sites. In this study, we investigate the mineralogy, carbon and oxygen isotopic compositions and the lipid biomarkers of a carbonate crust from the western Tekirdağ basin of the Sea of Marmara. This crust exhibits a laminated domal structure that resembles stromatolite. The mineralogy of authigenic seep-carbonate is mostly represented by aragonite associated with minor amounts of high-magnesian calcite. The abundance of pyrite associated with the authigenic seep-carbonate points to very intense bacterial sulfate reduction. The carbon $(-42.6 \%$ to $-34.4 \%$ ) and oxygen $(-1.5 \%$ to $+1.1 \%$ ) isotopic compositions of the authigenic seep-carbonate crust indicate that carbonate precipitation was related to anaerobic oxidation of methane and occurred in mixtures of bottom seawater with brackish water expelled from the underlying sediments. Abundant microbial lipid biomarkers with negative $\delta 13 \mathrm{C}$ values $(-121 \%$ o to $-96 \%)$, confirm that anaerobic oxidation of methane (AOM) coupled with sulfate reduction, was mediated by methanotrophic archaea (ANME) and sulfate reducing bacteria (SRB). Diagnostic lipid fingerprints indicate that ANME-2 archaea and associated SRB were the prevalent AOM-mediating consortia, which characterize moderate to high methane flow at this site. Moreover, changes in microbial lipid distribution within the carbonate crust suggest a variation in the intensity of methane emission.
\end{abstract}

Keywords: Marmara Sea, Tekirdağ Basin, methane, authigenic seep-carbonate, sulfate reduction, anaerobic oxidation of methane, stromatolitic structure, stable isotopes, lipid biomarkers 


\section{Introduction}

Cold seeps are areas spread worldwide along continental margins where fluids rich in methane and hydrogen sulfide are present within the shallow sedimentary column and partly released into the water column (Suess, 2014). Most of the methane migrating upward within the sedimentary column is microbially consumed at the sulfate-methane transition zone (SMTZ) through anaerobic oxidation of methane (AOM), this process leading to the main methane sink on Earth (Hinrichs and Boetius, 2002; Knittel and Boetius 2009; Reeburgh, 2007; Valentine and Reeburgh, 2000). It is commonly assumed that AOM involves microbial syntrophic consortia of methanotrophic archaea (ANME), and sulfate-reducing bacteria (SRB) (Boetius et al., 2000; Hinrichs et al., 1999; Orphan et al., 2002, 2001; Pancost et al., 2001, 2000). However, Milucka et al. (2012) have displayed that AOM is not necessarily associated with SBR. Molecular studies using fluorescence in situ hybridization and 16S ribosomal RNA gene sequence analysis revealed that AOM is mediated by at least three distinct clusters that are part of methanogenic archaea, ANME-1, ANME-2 and ANME-3 (Boetius et al., 2000; Hinrichs et al., 1999; Knittel et al., 2005; Niemann et al., 2006; Orphan et al., 2001). The production of bicarbonate ions during the AOM-SR process increases alkalinity in pore waters, which leads to the precipitation of authigenic carbonates (Claypool and Threlkeld 1983; Peckmann and Thiel, 2004). Indeed, many studies have shown that ${ }^{13} \mathrm{C}$ depleted lipid biomarkers synthesized by AOM microbial communities are contained in seep carbonates, supporting that these microbial consortia were involved in their precipitation (Aloisi et al., 2002, 2000; Bouloubassi et al., 2006; Chevalier et al., 2010, 2011; Gontharet et al., 2007; Greinert et al., 2002; Peckmann et al., 2001; Stadnitskaia et al., 2008). Moreover, the distribution of specific microbial lipid biomarkers (specific hydrocarbons, alcohols and fatty acids) and their carbon isotopic signature is frequently used to infer the taxonomic composition of microbial communities involved in AOM, which allow to distinguish the dominant AOM assemblages in cold seep ecosystems (see Blumenberg et al., 2004; Niemann and Elvert 2008 and references therein).

In the Sea of Marmara (SoM), a number of studies have shown that the authigenic carbonates in the cold seep environments were formed via the AOM process (Çağatay et al., this issue, Chevalier et al., 2011; Crémière et al., 2012). Moreover, the involvement of the dominant ANME-2 cluster associated with their specific SRB has been highlighted in several 
cold seep-related carbonates, and also in sediments, using molecular and isotopic approaches (Chevalier et al., 2013, 2011).

In this study, we examine in detail a seafloor authigenic carbonate crust recovered at an active fluid venting site in the SoM during the "MarsiteCruise" expedition in 2014 onboard the $\mathrm{R} / \mathrm{V}$ Pourquoi pas?. The main goal was to characterize the biogeochemical processes responsible for carbonate precipitation, using carbonate mineralogy, carbon and oxygen isotopic compositions of carbonate as well as the distribution and carbon isotopic compositions of lipid biomarkers.

\section{Geological setting and sampling}

The SoM is located between the Mediterranean Sea and the Black Sea in Turkish territory. It is composed of three distinct basins, named from west to east: Tekirdağ Basin, Central Basin and Çinarcik Basin (Fig. 1). The SoM is crossed along an east-west axis by the northern branch of the seismically active North Anatolian Fault (NAF) with the associated dense secondary-fault networks (Le Pichon et al., 2003, 2001). This whole fault system serves as conduits for fluid migration (Dupré et al., 2015). Bourry et al. (2009) and Ruffine et al. (this issue) reported that methane and other hydrocarbons from the seeping fluids in the Tekirdağ basin are mostly of thermogenic origin.

The studied carbonate crust was sampled during the dive MRS-DV4 with the remotely operated vehicle (ROV) Victor 6000 at an active seepage area located along the main fault scarp on the south-eastern part of the Tekirdağ Basin $\left(40^{\circ} 48^{\prime} 18^{\prime \prime} \mathrm{N}, 27^{\circ} 37^{\prime} 77^{\prime \prime} \mathrm{E} ; 1107 \mathrm{~m}\right.$ water depth) (Fig. 1, 2A, 2B). The site was already visited in 2007 during the Marnaut cruise with the submersible Nautile, and referred to as "Jack the Smoker" (Armijo et al., 2005, Burnard et al., 2012), due to fluid emission from decimeter-high carbonate chimneys forming a mound-shaped construction. The carbonate crust, when sampled at the "Jack the Smoker" site, was partly buried in mud and partly overhanging the seafloor; its surface bathed with seawater was covered by orange biofilms whereas white bacterial mat covered the crust at the contact of the black reduced sediment (Çağatay et al., this issue; Fig. 2A and 2B). The distribution of crust elements dispersed on the seafloor suggests they were probably broken due to seismic activity along the faulted area described in Armijo et al. (2005).

Recent experiments with the deployment of an osmo-sampler over one year close to the "Jack the Smoker" vent have measured background flow rates of 5-20 cm/yr interrupted by episodic high flow rates ( $1 \mathrm{~m} / \mathrm{yr})$, (Tryon et al., 2012). 


\section{Analytical methods}

\subsection{Mineralogy and stable isotopes}

Part of the frieze-dried carbonate crust was cut into several parallel slabs revealing their internal structure. One of these, showing the best textural details, was broken into 6 fragments (section 1', and 1 to 5) for analysis (Fig. 2C, Tables 1, 2 \& 3). One or several small parts of each, was sampled for bulk mineralogical and carbon and isotopic analyses (Table 1). Microsamples were collected to analyse the carbon and oxygen isotopic variability on the nearby slab (Fig. 2C). The subsamples were ground in an agate mortar to obtain a fine powder. The total carbonate content of bulk sediment (in weight \% of dry sediment, wt $\%$ ) was measured by reacting $100 \mathrm{mg}$ of the powder with $1 \mathrm{ml}$ of $\mathrm{HCl}-8 \mathrm{~N}$ in a manual calcimeter (precision of the measure: $\pm 1 \%$ ). The mineralogy of bulk sediment was determined through X-ray diffraction (XRD) of non-oriented powder, using a diffractometer (Bruker D2 Phaser) equipped with a Lynxeye detector, $\mathrm{Cu}-\mathrm{Ka}$ radiation $(\lambda=0.15406 \AA)$ and $\mathrm{Ni}$ filter at $30 \mathrm{kV}$ and $10 \mathrm{~mA}$. The position of the major diffraction peak (d104) of calcite was used to estimate the relative mole\% content of $\mathrm{MgCO}_{3}$ in the crystal lattice (Goldsmith et al., 1961). When necessary, the main quartz peak was used as a reference to correct the position of the 104 peak of calcite. Mineral identification was made using the Diffrac.Eva v4.1 software and the ICDD PDF2 database. The relative percentages of aragonite and calcite within the subsamples were estimated by measuring the peak area with MacDiff software. Scanning electron microscope (SEM) observations and elemental analysis were made on a few selected zones to characterize the crystal morphology, microstructure and elemental composition of carbonate minerals and other authigenic phases. 
The carbon and oxygen isotopic compositions of carbonates were measured on microsamples obtained by microdrill from a polished plate (Fig. $2 \mathrm{C}$ ) as well as on the samples from the 6 sections (Table 1). The $\delta^{18} \mathrm{O}$ and $\delta^{13} \mathrm{C}$ values of these samples were obtained by reaction of 100 to $200 \mu \mathrm{g}$ of powdered carbonate with anhydrous orthophosphoric acid for 12 minutes at $90^{\circ} \mathrm{C}$. The released $\mathrm{CO}_{2}$ was analyzed using an Isoprime Dual-Inlet isotopic ratio mass spectrometer equipped with a Multiprep system. The isotopic compositions are reported in delta $(\delta)$ units relative to the Vienna Pee Dee Belemnite reference (VPDB); sample bracketing was performed with the laboratory reference (Carrara marble; $\delta^{13} \mathrm{C}=+2.13 \%$ and $\delta^{18} \mathrm{O}=-1.83 \%$ o VPDB).

\subsection{Lipid biomarkers}

Lipids were extracted from $\approx 5 \mathrm{~g}$ (dried weight, $\mathrm{dw}$ ) of powdered carbonate sub-samples corresponding to the 6 sections with a $\mathrm{CH}_{2} \mathrm{Cl}_{2} / \mathrm{MeOH}$ mixture (2:1) by sonication (3 times). The total lipid extract was separated using a silica chromatography column into 3 fractions: F1 (hydrocarbons), F2 (ketones) and F3 (alcohols). An aliquot of the total extract was further saponified with $6 \% \mathrm{KOH}$ in methanol $\left(80^{\circ} \mathrm{C}, 1 \mathrm{~h}\right)$ and extracted with hexane to yield the neutral lipids. Fatty acids were then obtained by acidification of the residual phase to $\mathrm{pH}=1$ and extracted with hexane. For GC analyses, fatty acids were methylated using Boron Trifluoride with Methanol $\left(\mathrm{BF}_{3} / \mathrm{MeOH}\right)$ to form fatty acid methyl esters (FAMEs) and alcohols were derivatised (sylilation) with $\mathrm{N}, \mathrm{O}-$ bis(tri-methylsilyl)trifluoracetamide (BSTFA) and pyridine to form trimethylsilyl-(TMS)ethers.

All fractions were analysed by gas chromatography (GC) on an Agilent $6890 \mathrm{~N}$ instrument equipped with a column injector and a flame ionization detector (FID). A fused silica capillary column was used ( $30 \mathrm{~m} \times 0.32 \mathrm{~mm}$ inner diameter, $0.25 \mu \mathrm{m}$ film thickness) with helium as a carrier gas at $2.5 \mathrm{~mL} / \mathrm{min}$. The temperature program of the $\mathrm{GC}$ oven was as follows: (i) hydrocarbons: increase from 50 to $120^{\circ} \mathrm{C}$ at a rate of $30^{\circ} \mathrm{C} / \mathrm{min}$, then to $320^{\circ} \mathrm{C}$ at a rate of $5^{\circ} \mathrm{C} / \mathrm{min}$. The temperature was held at $320^{\circ} \mathrm{C}$ for $7 \mathrm{~min}$, (ii) alcohols: increase from 50 to $100^{\circ} \mathrm{C}$ at a rate of $30^{\circ} \mathrm{C} / \mathrm{min}$, then to $150^{\circ} \mathrm{C}$ at a rate of $15^{\circ} \mathrm{C} / \mathrm{min}$ followed by an increase to $300^{\circ} \mathrm{C}$ at a rate of $3^{\circ} \mathrm{C} / \mathrm{min}$. The temperature was then kept constant for $45 \mathrm{~min}$. (iii) Fatty acids: increase from 50 to $100^{\circ} \mathrm{C}$ at a rate of $30^{\circ} \mathrm{C} / \mathrm{min}$, then to $310^{\circ} \mathrm{C}$ at $2^{\circ} \mathrm{C} / \mathrm{min}$, and finally maintained at $310^{\circ} \mathrm{C}$ for $35 \mathrm{~min}$. Quantification was based on the GC-FID response relative 
to internal standards (perdeuterated n-tetracosane, androstanol, heneicosanol and nonadecanoic acid) within the respective lipid fraction.

For structural identification of lipids, gas chromatography-mass spectrometry (GC-MS) analysis was performed using an Agilent 7890A GC equipped with a fused silica capillary column (30 m x $0.25 \mathrm{~mm}$ inner diameter, $0.25 \mu \mathrm{m}$ film thickness) coupled to an Agilent $5975 \mathrm{C}$ MS instrument, which operated with an ionization energy of $70 \mathrm{eV}$ with a scanning mass range of $\mathrm{m} / \mathrm{z} 50-800$. The oven temperature program was the same as for the GC analysis.

Compound-specific stable carbon isotope composition was measured using an online continuous flow gas chromatograph Trace-GC-Ultra coupled with an Isotopic Ratio Mass Spectrometer Delta V Plus via a combustion and conflow IV interface from Thermo Fischer Scientific (GC-C-IRMS). The GC was equipped with a $30 \mathrm{~m}$ fused silica capillary column ( $0.25 \mathrm{~mm}$ inner diameter, $0.25 \mu \mathrm{m}$ film thickness). The temperature programs were the same as described above. Compositions are given in the delta notation as $\delta$-value (\%o), which is the relative deviation of the sample from the VPDB. The accuracy and reproducibility of the GC-C-IRMS measurements were assessed with a standard mixture of $n$-alkanes $\left(C_{16}\right.$ to $\left.C_{30}\right)$ purchased from Schimmelmann (Indiana University) of known isotopic composition. The $n$ alkane standard mixture (type A6) was injected three times at the beginning of each run and then once every 3 samples. Analytical standard deviation over the entire analyses was of \pm $0.6 \%(n=60)$. Isotopic values of alcohols and fatty acids were corrected for the presence of carbon atoms added during silylation ( $\delta^{13} \mathrm{C}$ BSTFA $\left.=-39.4 \pm 0.1 \%, \mathrm{n}=4\right)$ and methylation $\left(\delta^{13} \mathrm{C}\right.$ BF3-MeOH $\left.=-38.5 \pm 0.2 \%, n=6\right)$.

\section{Results}

\subsection{Macroscopic and microscopic observations}

The rather flat top of the crust, just below the dark reduced sediment, has a rough surface showing circular to ovoid cavities partially connected (Fig. 3A), of infra to pluri-mm size, that might correspond to former voids (gas bubbles or bioturbation?) within the organic-rich sediment (Fig. 2C). A few cavities show an inner dark to orange coating. The resulting carbonate facies correspond to most of the grey-coloured part of the crust showing, in thin section, the coalescence of round $100 \mu \mathrm{m}$ large micritic elements surrounded by fibrous aragonite, which forms a polygonal network of dark $10 \mu \mathrm{m}$ particles (Fig. 3B \& 3C). Pluri- 
centimetric larger cavities, with a flat top, are also observed (former filled by the black reduced sediment), displaying pluri-mm to $\mathrm{cm}$-sized dome-like structures on their borders.

Below the lower undulated surface of the larger cavities, domal structures develop downwards with alternating vacuolar layers, some of them parallel to their lower limit. Larger sequant pluri-mm large voids are also present. The more compact cream-coloured parts, especially at the bottom of the crust, exhibit thin laminations, made of $50 \mu \mathrm{m}$-thick orange or black layers separating irregular $200 \mu \mathrm{m}$ to mm-thick layers (Fig. 3D). In thin section, the former ones look like biofilms whereas the thicker aragonite layers have a grass-like facies, composed of tubes of around $50 \mu \mathrm{m}$ wide limited by darker spots corresponding to sulfides and/or organic matter.

During its growth, the crust maintained a contorted morphology prone to the living habitat of numerous gastropod and bivalve shells (mostly Idas simpsoni, S. Duperron, oral communication) that colonized the hard carbonate crust substrate and were later encrusted (Fig. 2C \& 3A).

\subsection{Mineralogy and carbon and oxygen isotope compositions of authigenic carbonate}

The crust is mainly composed of carbonate (64 to $95 \mathrm{wt} \%$ ) associated with few detrital minerals (mostly clay minerals), some authigenic pyrite, gypsum and sulfur. Aragonite (>77 $\%$, Table 1) and high-magnesian calcite (with $d_{104}$ values of calcite ranging between 3.009 and $3.012 \AA$ corresponding to $\sim 8$ mole $\% \mathrm{MgCO}_{3}$ ) are the dominant carbonate phases (Table 1).

The oxygen and carbon isotopic compositions of bulk carbonate from the sections vary from $0.2 \%$ to $+1.1 \%$ and from $-43.0 \%$ to $-36.3 \%$, respectively (Table 1 , Fig. 4 ). The microdrilled subsamples reveal a significant isotopic variability at the millimetric scale, with $\delta^{18} \mathrm{O}$ and $\delta^{13} \mathrm{C}$ values ranging from $-1.5 \%$ to $+1.0 \%$ and $-41.6 \%$ o to $-37.6 \%$, respectively (Table 1 , Fig. 4).

\subsection{Lipid biomarkers}

The lipid analysis reveals several archaeal compounds (Fig. 5A and 5B) including isoprenoidal dialkyl glycerol diethers represented by archaeol and sn-2-hydroxyarchaeol, saturated and unsaturated $\mathrm{C}_{20}$ (crocetane), as well as polyunsaturated irregular $\mathrm{C}_{25}$ 
isoprenoid alkenes with 2 to 4 unsaturations (2,6,10,15,19-pentamethylicosenes: PMI:2 to PMI:4) with PMI:3 being predominant. Heterogeneity in the biomarker concentration is observed from one carbonate section to another. Archaeol and sn-2-hydroxyarchaeol contents vary from 0.8 to $36.8 \mu \mathrm{g} / \mathrm{g} \mathrm{dw}$ (Table 2). PMls are the dominant compounds, except for sections 1 and 2 where archaeol is threefold more abundant. Another lipid with a phytanyl chain is also detected in lower amounts, i.e. phytanol (0.4 to $1.8 \mu \mathrm{g} / \mathrm{g} \mathrm{dw}$; Table 2).

All archaeal biomarkers in the crust are strongly depleted in ${ }^{13} \mathrm{C}$, suggesting incorporation of methane-derived carbon during their biosynthesis. PMls are the most depleted compounds with $\delta^{13} \mathrm{C}$ values from $-121 \%$ to $-112 \%$ whereas phytanol displays slightly higher $\delta^{13} \mathrm{C}$ values (-98 to $-96 \%$; Table 2). Crocetane/crocetene and isoprenoidal dialkyl glycerol diethers exhibit smaller variations with $\delta^{13} \mathrm{C}$ values from $-116 \%$ o to $-110 \%$ and $-106 \%$ to $-101 \%$, respectively (Table 2). Moreover, apolar compounds (PMls and their $\mathrm{C}_{20}$ homologues) are more ${ }^{13} \mathrm{C}$ depleted than polar lipids (archaeol and sn-2-hydroxyarchaeol) with a $\delta^{13} \mathrm{C}$ offset of $10-15 \%$ (Table 2).

Various bacterial lipids are also present (Fig. 5B and 5C). Among them, the most abundant compounds are $i-\mathrm{C}_{15: 0}$ and $\mathrm{C}_{16: 1 w 5}$ fatty acids (FAs) as well as a $\mathrm{C}_{18}$-OH FA (Table 3 ). Terminally branched ai- $\mathrm{C}_{15: 0}$ and $n-\mathrm{C}_{14: 0} \mathrm{FAs}$ occur at lower concentrations (3.5 to $33.4 \mu \mathrm{g} / \mathrm{g}$ dw; Table 3).

A sequence of $n$-alcohols $\left(n-\mathrm{C}_{14: 0}\right.$ to $\left.n-\mathrm{C}_{17: 1}\right)$ with negative $\delta^{13} \mathrm{C}$ values (-90 to $-70 \%$ ) are also detected in less abundance within the crust and they occur at concentrations ranging from 0.2 to $5.5 \mu \mathrm{g} / \mathrm{g} \mathrm{dw}$ (Table 3). Other major bacterial biomarkers are dialkyl glycerol diethers (DAGEs; Chevalier et al., 2011 and references therein). The summed concentrations of the DAGEs are relatively high, ranging from 8.9 to $19.7 \mu \mathrm{g} / \mathrm{g} \mathrm{dw}$ (Table 3).

All bacterial lipids show negative $\delta^{13} \mathrm{C}$ values with a range from $-100 \%$ to $-68 \%$ o. Moreover, i/ai- $\mathrm{C}_{15: 0}$ and $\mathrm{C}_{18}$-OH FAs show the most negative $\delta^{13} \mathrm{C}$ values around an average of $-97 \%$ (Table 3). Compared to archaeal lipid biomarkers, bacterial lipids exhibit less negative $\delta^{13} \mathrm{C}$ values with $\delta^{13} \mathrm{C}$ offset of $10-40 \%$ between archaeal and bacterial lipids.

\section{Discussion}

\subsection{Formation process of the authigenic seep-carbonate crust}

The characteristic lithofacies of the studied seep-carbonate crust is the wavy laminae pattern similar to stromatolitic fabric (Fig. 2C, 3A, 3C, 3D). This stromatolitic morphology in seep- 
carbonate, indicating a microbial activity, was first documented in marine authigenic seepcarbonate at a depth of $4,850 \mathrm{~m}$ on the Aleutian accretionary margin (Greinert et al., 2002) and more recently on offshore Nicaragua and Costa Rica in massive methane-derived authigenic seep-carbonates from mound caps (Liebetrau et al., 2014). Typically, the authigenic seep-carbonate crusts grow downwards in the sediment, and progressively make hardgrounds at the seafloor, which prevent the upward fluid flow reaching the bottom water except along conduits, fractures and where the seafloor remains uncemented.

Within the DV04-CC1 crust, authigenic seep-carbonates are mainly composed of aragonite ( 77 to 99 relative wt \%) with minor to moderate contributions of high-Mg calcite (1 to 23 relative wt \%). The mineralogy of carbonates is influenced by several physico-chemical conditions such as temperature, $\mathrm{SO}_{4}{ }^{2-}$ concentrations and $\mathrm{Mg}^{2+} / \mathrm{Ca}^{2+}$ ratio (Burton and Walter, 1987; De Choudens-Sanchez and Gonzalez, 2009). The bottom water of the SoM is characterized by warm temperature $\left(14.5^{\circ} \mathrm{C}\right)$ and $\mathrm{SO}_{4}{ }^{2-}$ concentrations and $\mathrm{Mg}^{2+} / \mathrm{Ca}^{2+}$ ratio similar to those of Mediterranean bottom water (Ruffine et al., this issue; Tryon et al., 2010; Zitter et al., 2008) that would favour aragonite precipitation (Fig. 6A, 6B, 6D \& 6H). High methane flow is also inferred to promote aragonite formation (Nöthen and Kasten, 2011).

The incorporation of dissolved inorganic carbon (DIC) produced by the oxidation of methane is reflected in the carbon isotopic composition of the carbonate crust with $\delta^{13} \mathrm{C}$ values as low as $-42.6 \%$. The sub-samples of the carbonate crust also contain highly ${ }^{13} \mathrm{C}$-depleted archaeal and bacterial lipids attesting for the incorporation of methane-derived carbon into microbial biomass (e.g. Kellermann et al., 2012; Wegener et al., 2008). The presence of ${ }^{13} \mathrm{C}$ depleted microbial lipid biomarkers thus indicate the involvement of methanotrophic archaea (ANME) associated with sulfate reducers in the carbonate formation via anaerobic oxidation of methane (AOM) coupled with bacterial sulfate reduction (SR). This is consistent with previous studies reported for carbonate crust and sediment retrieved from cold seeps (Aloisi et al., 2002; Bouloubassi et al., 2006; Chevalier et al., 2014, 2013, 2011, 2010; Elvert et al., 2000, 1999; Gontharet et al., 2009; Greinert et al., 2002; Hinrichs et al., 2000, 1999; Pancost and Sinninghe Damsté, 2003; Pancost et al., 2001, 2000; Stadnitskaia et al., 2008; Thiel et al., 1999). The presence of pyrite $\left(\mathrm{FeS}_{2}\right)$ as framboids and single crystals (Fig. 6C, 6E, 6F, $6 \mathrm{G}, 6 \mathrm{I})$ is also a signature of hydrogen sulfide formation associated with the AOM process (Aloisi et al., 2000; Crémière et al., 2012; Greinert et al., 2002; Naehr et al., 2007; Pierre et al., 2012). Indeed, pyrite is ubiquitous in anoxic sediments, where dissolved iron reacts with hydrogen sulfide produced by bacterial sulfate reduction and is precipitated as sulfide minerals (Berner, 1984). The abundance of pyrite in diagenetic carbonates from the Marmara Sea confirms that microbial sulfate reduction was a very active process during carbonate 
precipitation (Crémière et al., 2012). The presence of sulfur (Fig. 6E), iron oxides (Fig. 6G) and gypsum (Fig. 6E) in association with pyrite indicates that further oxidation of pyrite occurred when the carbonate crust was exposed to oxygenated bottom water conditions.

Although $A O M / S R$ is the major process underlying the carbonate precipitation, methanederived carbon may not be the only carbon source implied in the formation of the crust. Indeed, the difference between the carbon isotopic compositions of methane at this site ($66.1<\delta^{13} \mathrm{C} \%$ VPDB $<-63.8$; Ruffine et al., this issue) and those of the carbonate crust sections $\left(\Delta \delta^{13} \mathrm{C}=21.2-28.8 \%\right.$ ) indicate the admixture of at least one additional carbon source, especially from the pool of ${ }^{13} \mathrm{C}$-enriched DIC (e.g., Mazzini et al., 2004; Pierre and Fouquet, 2007). Such a DIC source would be issued from oxidation of non-methane hydrocarbons (Formolo et al., 2004), characterized by carbon isotopic composition between $37 \%$ and $-29 \%$ (Ruffine et al, this issue). Moreover, the DIC produced by remineralization of organic matter from marine sediments (with an average $\delta^{13} \mathrm{C}$ value of $-25 \%$ ) may be another carbon source (Crémière et al., 2012).

The oxygen isotopic composition of the bottom water of the Sea of Marmara $(+1.6 \%$ o VSMOW: Standard Mean Oceanic Water reference; Rank et al., 1999) was used to estimate the theoretical $\delta^{18} \mathrm{O}$ of aragonite that would precipitate in isotopic equilibrium at $14.5^{\circ} \mathrm{C}$ with the present-day bottom seawater, following the Böhm et al (2000) equation:

$$
\mathrm{T}^{\circ} \mathrm{C}=20-4.42\left(\delta^{18} \mathrm{O} \text { aragonite VPDB }-\delta^{18} \mathrm{O} \text { water VSMOW }\right)
$$

Similar estimation was made for calcite, using the equation of Kim and O'Neil (1997), corrected by $0.06 \%$ for each mole $\%$ of $\mathrm{MgCO}_{3}$ (Tarutani et al., 1969).

$$
1000 \ln \alpha^{18} \mathrm{O} \text { calcite-water }=18.03\left(10^{3} \mathrm{~T}^{-1}\right)-32.42
$$

These equations give the $\delta^{18} \mathrm{O}$ values of $+2.8 \%$ for aragonite and $+2.0 \%$ for calcite containing $8 \%$ of $\mathrm{MgCO}_{3}$, precipitated at equilibrium under the present-day bottom water conditions defined above.

In the studied carbonate crust, all samples exhibit $\delta^{18} \mathrm{O}$ values lower than these equilibrium values, thus indicating that carbonate precipitated with mixtures of bottom seawater with variable contribution of water with a negative $\delta^{18} \mathrm{O}$ value. The $\delta^{18} \mathrm{O}$ values of these mixed waters are estimated to range between $-0.1 \%$ and $-2.7 \%$, for aragonite with $\delta^{18} \mathrm{O}$ values ranging between $+1.1 \%$ and $-1.5 \%$ o precipitated at the present-day bottom temperature. Indeed, the sampling site, "Jack the Smoker", is characterized by expulsion of brackish fluids issued from underlying sediments deposited during the last glacial period when brackish 
conditions existed in the Sea of Marmara (Çağatay et al., this issue; Crémière et al., 2012; Tryon et al., 2010; Zitter et al., 2008). These brackish waters are characterized by low $\mathrm{Cl}^{-}$ content $(231 \mathrm{mM})$ and negative $\delta^{18} \mathrm{O}$ values (-5.5\% VSMOW), as measured in pore waters of a core located on the Western High (Aloisi et al., 2015). This allows for the estimation of the fraction of the brackish water that mixed with bottom seawater to form the mixture from which the studied carbonate crust precipitated; the fraction is estimated between 0.3 and 0.6 .

\subsection{Composition of AOM microbial communities during stromatolitic carbonate precipitation}

Specific lipid biomarker fingerprints obtained from the six subsamples clearly indicate the presence of both archaeal clusters, ANME-1 and ANME-2. Generally, cold seep settings host several ANME groups, knowing that only one dominates the microbial community. Each assemblage produces specific ${ }^{13} \mathrm{C}$-depleted lipids in different amounts, which determine the dominant ANME group involved in AOM (Niemann and Elvert, 2008). PMls are synthesized by both ANME-1 and ANME-2 clades (Blumenberg et al., 2004). However, the $\delta^{13} \mathrm{C}$ offset of $10-15 \%$ observed between PMls and isoprenoidal glycerol diethers, point to a preferential synthesis of PMls by ANME-2 archaeal lineage (Blumenberg et al., 2005; Chevalier et al., 2014; Niemann and Elvert, 2008). This result is supported by the abundance of crocetane and its unsaturated counterparts together with PMIs. The dominance of ANME-2 community is also supported in subsamples 1 and 4 by the prevalence of sn-2-hydroxyarchaeol over archaeol (ratios 3 and 1.22, respectively; Niemann and Elvert, 2008). On the contrary, archaeol predominates over sn-2-hydroxyarchaeol in subsamples $1,2,3$ and 5 (ratios 0.11 , $0.02,0.42$ and 0.66 respectively), which suggests a higher proportion of ANME-1 archaea in the microbial pool in these subsamples (Blumenberg et al., 2004; Niemann and Elvert, 2008).

The bacterial patterns are in line with the ANME-2 inferred archaeal lipid data. The low ratio of ai- $\mathrm{C}_{15: 0}$ relative to $i-\mathrm{C}_{15: 0} \mathrm{FAs}(0.3$ to 0.6$)$ and the presence of compounds such as $n-\mathrm{C}_{14: 0}$ and $\mathrm{C}_{16: 1 \mathrm{w} 5}$ were observed in the samples. These lipid patterns suggest a dominance of SRB eco-types that have been found associated with ANME-2 (Hinrichs et al., 2000; Niemann and Elvert, 2008), in accordance with the distribution of non-isoprenoid dialkyl glycerol ethers (DAGEs) with negative $\delta^{13} \mathrm{C}$ values in carbonate crusts from the three basins of the Marmara Sea (Chevalier et al., 2011). In this study, DAGEs were attributed to sulfate reducing bacteria in syntrophy with ANME-2 archaea. 
The presence of ${ }^{13} \mathrm{C}$-depleted phytanol, a methanotroph archaea-derived lipid (Ge et al., 2015; Niemann and Elvert, 2008; Thiel et al., 1999) is also observed. However, the $\delta^{13} \mathrm{C}$ values $\left(-98<\delta^{13} \mathrm{C} \%\right.$ VPDB $\left.<-96\right)$ of phytanol are slightly heavier than in other archaeal biomarkers. This isotopic composition might be induced by a small contribution of phytanol synthetized by microorganisms different to ANMEs (Elvert et al., 2000). The distribution of short-chain $n$-alcohols present in the studied carbonate crust (from $n-\mathrm{C}_{14: 0}$ to $n-\mathrm{C}_{17: 1}$ ) showed $\delta^{13} \mathrm{C}$ values ranging between $-70 \%$ and $-85 \%$. These compounds have more positive $\delta^{13} \mathrm{C}$ values than archaeal lipids, which indicate different source organisms and thus, a potential origin from sulfate reducing bacteria with an autotrophic growth on methane-derived dissolved inorganic carbon (e.g. Hinrichs and Boetius, 2002; Wegener et al., 2008 and references therein). Another peculiar result is the presence of a $\mathrm{C}_{18}$ FAME with a hydroxyl group $\left(\mathrm{C}_{18}-\mathrm{OH} F A\right)$ in high quantities throughout the carbonate and characterized by very negative $\delta^{13} \mathrm{C}$ values. The specific isotopic signature strongly indicates the incorporation of methane-derived carbon by their microbial precursor. The presence of this fatty acid was never previously observed in AOM-related environments (sediment core or carbonate). Their $\delta^{13} \mathrm{C}$ values identical to those of archaeol and sn-2-hydroxyarchaeol, combined with the absence of any isoprenoidal carbon structure, discards an archaeal origin (Volkman, 2006). Indeed, long-chain hydroxyl fatty acids can be related to methanotrophic bacteria (Skerratt et al., 1992). Despite the fact that there is no available DNA data to confirm this precursor, it may be suggested that methanotrophic bacteria could be a potential biological source of the ${ }^{13} \mathrm{C}$-depleted $\mathrm{C}_{18} \mathrm{OH}$ FA.

Previous studies have shown that the taxonomy of microbial consortia in AOM environments depends on specific conditions such as temperature, methane concentration and degree of anoxia (Knittel et al., 2005; Nauhaus et al., 2002, 2005; Treude et al., 2003). For instance, the intensity of methane flow would be a factor to explain the presence of different types of ANME (ANME-1 vs. ANME-2) (Blumenberg et al., 2004; Rossel et al., 2011; Stadnitskaia et al., 2008). The lipid biomarker patterns of the studied carbonate crust indicate a predominance of ANME-2 consortia suggesting that the carbonate crust was formed via AOM during moderate to high methane flux conditions (Blumenberg et al., 2004; Knittel et al., 2005; Rossel et al., 2011; Stadnitskaia et al., 2008). However, we observe changes in the distribution of lipid biomarkers with a net dominance of ANME-2 community associated with their specific SRB in sections 1' and 4, and higher proportions of ANME-1/SRB in the other sections. These differences in ${ }^{13} \mathrm{C}$-depleted microbial lipid composition might indicate the variability of in situ methane and sulfate concentration during these different precipitation phases, probably due to fault dynamics (Ruffine et al., 2015). This model was also 
demonstrated in the study of Stadnitskaia et al. (2008) with a clear change of archaeal community during the formation of an AOM-related carbonate crust that was attributed to a change in methane flow within the sediments. While changes of methane flux and anoxic conditions may control the AOM community structure, the $\delta^{13} \mathrm{C}$ values of archaeal and bacterial lipid biomarkers remain here relatively constant during the carbonate precipitation phases, which indicates a common source of methane used by AOM-related microbial assemblages during carbonate formation.

Consequently, the distribution of microbial lipid biomarkers could be used as a molecular proxy to estimate the paleochanges of methane emission and hypoxic/anoxic conditions in relation with seismic dynamics.

\section{Conclusions}

Observations of an authigenic carbonate crust taken from an active methane seep in the Tekirdağ Basin of the Sea of Marmara, together with mineralogical, isotopic and molecular geochemical analyses, made it possible to highlight the biogeochemical processes responsible for its formation. The major conclusions of this study are:

(i) Microbial activity is indicated by a laminated structure similar to a stromatolitic fabric.

(ii) A high amount of ${ }^{13} \mathrm{C}$-depleted archaeal and bacterial lipids associated with very negative $\delta^{13} \mathrm{C}$ values of $\mathrm{CaCO}_{3}$ in the different sections, and microprofiles, provide evidence for a carbonate formation by way of AOM and SR activity, mediated by ANME methanotrophic archaea and SRB members.

(iii) Lipid biomarker patterns indicate that the dominant AOM assemblages consist of ANME-2 archaea and associated SRB, suggesting carbonate formation in environments with moderate to high methane flow. Moreover, a variability of microbial community composition is observed through the carbonate structure, confirming changes in methane fluxes emitted along the NAF.

(iv) The presence of a ${ }^{13} \mathrm{C}$-depleted hydroxyl fatty acid $\left(\mathrm{C}_{18-\mathrm{OH}}\right)$ in this cold seep carbonate probably indicate that bacteria are involved during anaerobic methane oxidation. 


\section{Acknowledgements}

We thank the captain and his crew on-board the RV Pourquoi pas? and the team of the ROV Victor-6000 crew for their technical support and advice. Financial support was provided by the European programme "MARsite", under the call ENV.2012.6.4-2: "Long-term monitoring experiment in geologically active regions of Europe prone to natural hazards: the Supersite concept". We also thank the ALYSES facility (IRD-UPMC) that was supported by grants from Région Ile-de-France for molecular isotope analyses. Thanks are also due to Alison Chalm who kindly helped to improve the English text. Finally, we thank Tobias Himmler, two other anonymous reviewers and the guest editor for their constructive comments that have greatly contributed in improving the manuscript.

\section{References}

Aloisi, G., Soulet, G., Henry, P., Wallmann, K., Sauvestre, R., Vallet-Coulomb, C., Lécuyer, C., Bard, E., 2015. Freshening of the Marmara Sea prior to its post-glacial reconnection to the Mediterranean Sea. Earth Planet. Sci. Lett, 413, 176-185. doi :10.1016j.epsI.2014.12.052

Aloisi, G., Bouloubassi, I., Heijs, S.K., Pancost, R.D., Pierre, C., Sinninghe Damsté, J.S., Gottschal, J.C., Forney, L.J., Rouchy, J.-M., 2002. CH4-consuming microorganisms and the formation of carbonate crusts at cold seeps. Earth Planet. Sci. Lett. 203, 195-203. doi:10.1016/S0012-821X(02)00878-6

Aloisi, G., Pierre, C., Rouchy, J.-M., Foucher, J.-P., Woodside, J., 2000. Methane-related authigenic carbonates of eastern Mediterranean Sea mud volcanoes and their possible relation to gas hydrate destabilisation. Earth Planet. Sci. Lett. 184, 321-338. doi:10.1016/S0012-821X(00)00322-8

Armijo, R., Pondard, N., Meyer, B., Ucarkus, G., De Lépinay, B.M., Malavieille, J., Dominguez, S., Gustcher, M.A., Schmidt, S., Beck, C., Cagatay, N., Cakir, Z., Imren, C., Eris, K., Natalin, B., Özalaybey, S., Tolun, L., Lefévre, I., Seeber, L., Gasperini, L., Rangin, C., Emre, O., Sarikavak, K., 2005. Submarine fault scarps in the Sea of Marmara pull-apart (North Anatolian Fault): Implications for seismic hazard in Istanbul. Geochemistry, Geophys. Geosystems 6, 1-29. doi:10.1029/2004GC000896

Berner, R.A. 1984. Sedimentary pyrite formation: an update.Geochim. Cosmochim. Acta, $48,605-615$. 
Blumenberg, M., Seifert, R., Nauhaus, K., Pape, T., 2005. In Vitro Study of Lipid Biosynthesis in an Anaerobically Methane-Oxidizing Microbial Mat. Society 71, 4345-4351. doi:10.1128/AEM.71.8.4345

Blumenberg, M., Seifert, R., Reitner, J., Pape, T., Michaelis, W., 2004. Membrane lipid patterns typify distinct anaerobic methanotrophic consortia. Proc. Natl. Acad. Sci. U. S. A. 101, 11111-6. doi:10.1073/pnas.0401188101

Boetius, A., Ravenschlag, K., Schubert, C.J., Rickert, D., Widdel, F., Gieseke, A., Amann, R., Jørgensen, B.B., Witte, U., Pfannkuche, O., 2000. A marine microbial consortium apparently mediating anaerobic oxidation of methane. Nature 407, 623-6. doi:10.1038/35036572

Böhm, F., Joachimski, M.M., Dullo, W.C., Esisenhauer, A., Lehnert, H., Reitner, J., Wörheide, G., 2000. Oxygen isotope fractionation in marine aragonite of coralline sponges. Geochim. Cosmochim. Acta, 64, 10, 1695-1703.

Bouloubassi, I., Aloisi, G., Pancost, R.D., Hopmans, E., Pierre, C., Sinninghe Damsté, J.S., 2006. Archaeal and bacterial lipids in authigenic carbonate crusts from eastern Mediterranean mud volcanoes. Org. Geochem. 37, 484-500. doi:10.1016/j.orggeochem.2005.11.005

Bourry, C., Chazallon, B., Charlou, J.L., Pierre Donval, J., Ruffine, L., Henry, P., Geli, L., Çagatay, M.N., Inan, S., Moreau, M., 2009. Free gas and gas hydrates from the Sea of Marmara, Turkey. Chemical and structural characterization. Chem. Geol. 264, 197-206. doi:10.1016/j.chemgeo.2009.03.007

Burnard, P., Bourlange, S., Henry, P., Geli, L., Tryon, M., Sengör, A., Özeren, M., Çagatay, M., 2012. Constraints on fluid origins and migration velocities along the Marmara Main Fault (Sea of Marmara, Turkey) using helium isotopes. Earth and Planet. Sci. Lett. 341, 68-78.

Burton, E. A., Walter, L.M., 1987. Relative precipitation rates of aragonite and Mg calcite from seawater: temperature or carbonate ion control? Geology 15, 111-114. doi:10.1130/0091-7613(1987)15<111:RPROAA>2.0.CO

Çağatay, M. N., Yildiz, G., Bayon, G., Ruffine, L., Henry, P., 2017. Seafloor authigenic carbonate crusts along the submerged part of the North Anatolian Fault in the Sea of Marmara: Mineralogy, geochemistry, textures and genesis. Deep-Sea Research Part II: Topical Studies in Oceanography. https://doi.org/10.1016/j.dsr2.2017.09.003

Chevalier, N., Bouloubassi, I., Stadnitskaia, A., Taphanel, M.H., Sinninghe Damsté, J.S., 
2014. Lipid biomarkers for anaerobic oxidation of methane and sulphate reduction in cold seep sediments of Nyegga pockmarks (Norwegian margin): Discrepancies in contents and carbon isotope signatures. Geo-Marine Lett. 34, 269-280. doi:10.1007/s00367-014-0363-5

Chevalier, N., Bouloubassi, I., Birgel, D., Taphanel, M.H., López-García, P., 2013. Microbial methane turnover at Marmara Sea cold seeps: A combined 16S rRNA and lipid biomarker investigation. Geobiol. 11, 55-71. doi:10.1111/gbi.12014

Chevalier, N., Bouloubassi, I., Birgel, D., Crémière, A., Taphanel, M.H., Pierre, C., 2011. Authigenic carbonates at cold seeps in the Marmara Sea (Turkey): A lipid biomarker and stable carbon and oxygen isotope investigation. Mar. Geol. 288, 112-121. doi:10.1016/j.margeo.2011.08.005

Chevalier, N., Bouloubassi, I., Stadnitskaia, A., Taphanel, M.-H., Lorre, A., Sinninghe Damsté, J., Pierre, C., 2010. Distributions and carbon isotopic compositions of lipid biomarkers in authigenic carbonate crusts from the Nordic margin (Norwegian Sea). Org. Geochem. 41, 885-890.

Claypool, G.E., Threlkeld, C.N., 1983. Anoxic diagenesis and methane generation in sediments of the Blake Outer Ridge, Deep Sea Drilling Project Site 533, Leg 76. In: Sheridan, R.E., Gradstein, F.M., et al., Init. Repts. DSDP, 76: Washington (U.S. Govt. Printing Office), 391- 402.

Crémière, A., Pierre, C., Blanc-Valleron, M.-M., Zitter, T., Çağatay, M.N., Henry, P., 2012. Methane-derived authigenic carbonates along the North Anatolian fault system in the Sea of Marmara (Turkey). Deep Sea Res. Part I Oceanogr. Res. Pap. 66, 114-130. doi:10.1016/j.dsr.2012.03.014

De Choudens-Sanchez, V., Gonzalez, L. a., 2009. Calcite and Aragonite Precipitation Under Controlled Instantaneous Supersaturation: Elucidating the Role of $\mathrm{CaCO} 3$ Saturation State and Mg/Ca Ratio on Calcium Carbonate Polymorphism. J. Sediment. Res. 79, 363-376. doi:10.2110/jsr.2009.043

Dupré, S., Scalabrin, C., Grall, C., Augustin, J.-M., Henry, P., Sengor, A.M.C., Goeruer, N., Cagatay, M.N., Geli, L., 2015. Tectonic and sedimentary controls on widespread gas emissions in the Sea of Marmara: Results from systematic, shipborne multibeam echo sounder water column imaging. Journ. of Geophys. Res.-Solid Earth 120, 2891-2912.

Elvert, M., Suess, E., Greinert, J., Whiticar, M.J., 2000. Archaea mediating anaerobic methane oxidation in deep-sea sediments at cold seeps of the eastern Aleutian subduction 
zone. Org. Geochem. 31, 1175-1187. doi:10.1016/S0146-6380(00)00111-X

Elvert, M., Suess, E., Whiticar, M.J., 1999. Anaerobic methane oxidation associated with marine gas hydrates: superlight $C$-isotopes from saturated and unsaturated $C 20$ and $C 25$ irregular isoprenoids. Naturwissenschaften 86, 295-300. doi:10.1007/s001140050619

Formolo, M.J., Lyons, T.W., Zhang, C., Kelley, C., Sassen, R., Horita, J., 2004. Quantifying carbon sources in the formation of authigenic carbonates at gas hydrate sites in the Gulf of Mexico. Chemical Geology 205, 253-264.

Ge, L., Jiang, S.-Y., Blumenberg, M., Reitner, J., 2015. Lipid biomarkers and their specific carbon isotopic compositions of cold seep carbonates from the South China Sea. Mar. Pet. Geol. 66, 1-10. doi:10.1016/j.marpetgeo.2015.02.005

Goldsmith, J.R., Graf, D.L., Heard, H.C.,1961. Lattice constants of the calcium-magnesium carbonates. Amer. Mineral.4 6,453-457.

Gontharet, S., Stadnitskaia, A., Bouloubassi, I., Pierre, C., Damsté, J.S.S., 2009. Palaeo methane-seepage history traced by biomarker patterns in a carbonate crust, Nile deep-sea fan (Eastern Mediterranean Sea). Mar. Geol. 261, 105-113. doi:10.1016/j.margeo.2008.11.006

Gontharet, S., Pierre, C., Blanc-Valleron, M.M., Rouchy, J.M., Fouquet, Y., Bayon, G., Foucher, J.P., Woodside, J., Mascle, J., 2007. Nature and origin of diagenetic carbonate crusts and concretions from mud volcanoes and pockmarks of the Nile deep-sea fan (eastern Mediterranean Sea). Deep. Res. Part II Top. Stud. Oceanogr. 54, 1292-1311. doi:10.1016/j.dsr2.2007.04.007

Greinert, J., Bohrmann, G., Elvert, M., 2002. Stromatolitic fabric of authigenic carbonate crusts: Result of anaerobic methane oxidation at cold seeps in 4,850 m water depth. Int. J. Earth Sci. 91, 698-711. doi:10.1007/s00531-001-0244-9

Hinrichs, K., Boetius, A., 2002. The Anaerobic Oxidation of Methane: New Insights in Microbial Ecology and Biogeochemistry. In: Wefer G., Billett D., Hebbeln D., Jørgensen B.B., Schlüter M., van Weering T.C.E. (eds) Ocean Margin Systems. Springer, Berlin, Heidelberg, pp 457-477.

Hinrichs, K.-U., Summons, R.E., Orphan, V., Sylva, S.P., Hayes, J.M., 2000. Molecular and isotopic analysis of anaerobic methane-oxidizing communities in marine sediments. Org. Geochem. 31, 1685-1701. doi:10.1016/S0146-6380(00)00106-6. 
Hinrichs, K., Hayes, J.M., Sylva, S.P., 1999. Methane-consuming archaebacteria in marine sediments 398, 802-805. doi:10.1038/19751

Kellermann, M.Y., Wegner, G., Elvert, M., Yukio Yoshinaga, M., Lin, Y.S., Holler, T., Prieto Mollar, X., Knittel, K., Hinrichs, K.-U., 2012. Autotrophy as a predominant mode of carbon fixation in anaerobic methane-oxidizing microbial communities. Proc. Natl. Acad. Sci. U S A 109, 19321-19326.

Kim,S.T., O'Neil,J.R.,1997. Equilibrium and non equilibrium oxygen isotope effects in synthetic carbonates. Geochim. Cosmochim. Acta 61-16,3461-3475.

Knittel, K., Boetius, A., 2009. Anaerobic oxidation of methane: progress with an unknown process. Annu. Rev. Microbiol. 63, 311-34. doi:10.1146/annurev.micro.61.080706.093130

Knittel, K., Lösekann, T., Boetius, A., Kort, R., Amann, R., Lo, T., 2005. Diversity and Distribution of Methanotrophic Archaea at Cold Seeps Diversity and Distribution of Methanotrophic Archaea at Cold Seeps †. Appl. Environ. Microbiol. 71, 467-479. doi:10.1128/AEM.71.1.467

Le Pichon, X., Chamotrooke, N., Rangin, C., Sengor, A.M.C., 2003. The North Anatolian fault in the Sea of Marmara. Journ. of Geophys. Res.-Solid Earth 108.

Le Pichon, X., Sengor, A.M.C., Demirbag, E., Rangin, C., Imren, C., Armijo, R., Gorur, N., Cagatay, M. N., de Lepinay, B.M., Meyer, B., Saatcilar, R., Tok, B., 2001. The active Main Marmara Fault. Earth and Planet. Sci. Lett. 192, 595-616.

Liebetrau, V., Augustin, N., Kutterolf, S., Schmidt, M., Eisenhauer, A., Garbe-Schönberg, D., Weinrebe, W., 2014. Cold-seep driven carbonate deposits at the Central American forearc: contrasting evolution and timing in escarpment and mound settings. Int. J. Earth Sci.,103:1845-1872. doi 10.1007/s00531-014-1045-2

Milucka, J., Ferdelman T.G., Polerecky L., Franzke D., Wegener G., Schmid M., Lieberwirth I., Wagner M., Widdel F., Kuypers M.M.M., 2012. Zeor-valent sulphur is a key intermediate in marine methane oxidation. Nature 491, 541-546. doi:10.1038/nature11656.

Naehr, T.H., Eichhubl, P., Orphan, V.J., Hovland, M., Paull, C.K., Ussler, W., Lorenson, T.D., Greene, H.G., 2007. Authigenic carbonate formation at hydrocarbon seeps in continental margin sediments: A comparative study. Deep. Res. Part II Top. Stud. Oceanogr. 54, 12681291. doi:10.1016/j.dsr2.2007.04.010

Nauhaus, K., Treude, T., Boetius, A., Krüger, M., 2005. Environmental regulation of the 
anaerobic oxidation of methane: A comparison of ANME-I and ANME-II communities. Environ. Microbiol. 7, 98-106. doi:10.1111/j.1462-2920.2004.00669.x

Nauhaus, K., Boetius, A., Krüger, M., Widdel, F., 2002. In vitro demonstration of anaerobic oxidation of methane coupled to sulphate reduction in sediments from a marine gas hydrate area. Environ. Microbiol. 4, 296-305.

Niemann, H., Elvert, M., 2008. Diagnostic lipid biomarker and stable carbon isotope signatures of microbial communities mediating the anaerobic oxidation of methane with sulphate. Org. Geochem. 39, 1668-1677. doi:10.1016/j.orggeochem.2007.11.003

Niemann, H., Lösekann, T., de Beer, D., Elvert, M., Nadalig, T., Knittel, K., Amann, R., Sauter, E.J., Schlüter, M., Klages, M., Foucher, J.P., Boetius, A., 2006. Novel microbial communities of the Haakon Mosby mud volcano and their role as a methane sink. Nature 443, 854-8. doi:10.1038/nature05227

Nöthen, K., Kasten S., 2011. Reconstructing changes in seep activity by means of pore water and solid phase $\mathrm{Sr} / \mathrm{Ca}$ and $\mathrm{Mg} / \mathrm{Ca}$ ratios in pockmark sediments of the Northern Congo Fan. Mar Geol 287:1-13

Orphan, V.J., House, C.H., Hinrichs, K.-U., McKeegan, K.D., DeLong, E.F., 2002. Multiple archaeal groups mediate methane oxidation in anoxic cold seep sediments. Proc. Natl. Acad. Sci. 99, 7663-7668. doi:10.1073/pnas.072210299

Orphan, V.J., House, C.H., Hinrichs, K., 2001. Methane-Consuming Archaea Revealed by Directly Coupled Isotopic and Phylogenetic Analysis. Science (80-. ). 293, 484-488. doi:10.1126/science.1061338

Pancost, R.D., Sinninghe Damsté, J.S., 2003. Carbon isotopic compositions of prokaryotic lipids as tracers of carbon cycling in diverse settings. Chem. Geol. 195, 29-58. doi:10.1016/S0009-2541(02)00387-X

Pancost, R.D., Bouloubassi, I., Aloisi, G., Sinninghe Damsté, J.S., Scientific Party, the M.S., 2001. Three series of non-isoprenoidal dialkyl glycerol diethers in cold-seep carbonate crusts. Org. Geochem. 32, 695-707. doi:10.1016/S0146-6380(01)00015-8

Pancost, R.D., Sinninghe Damste, J.S., de Lint, S., van der Maarel, M.J.E.C., Gottschal, J.C., 2000. Biomarker Evidence for Widespread Anaerobic Methane Oxidation in Mediterranean Sediments by a Consortium of Methanogenic Archaea and Bacteria. Appl. Environ. Microbiol. 66, 1126-1132. doi:10.1128/AEM.66.3.1126-1132.2000 
Peckmann, J., Thiel, V., 2004. Carbon cycling at ancient methane-seeps. Chemical Geology 205, 443-467

Peckmann, J., Reimer, A., Luth, U., Luth, C., Hansen, B.T., Heinicke, C., Hoefs, J., Reitner, J., 2001. Methane-derived carbonates and authigenic pyrite from the northwestern Black Sea. Mar. Geol. 177, 129-150. doi:10.1016/S0025-3227(01)00128-1

Pierre, C., Blanc-Valleron, M.M., Demange, J., Boudouma, O., Foucher, J.P., Pape, T., Himmler, T., Fekete, N., Spiess, V., 2012. Authigenic carbonates from active methane seeps offshore southwest Africa. Geo-Marine Lett. 32, 501-513. doi:10.1007/s00367-012-0295-x

Pierre, C., Fouquet, Y., 2007. Authigenic carbonates from methane seeps of the Congo deep-sea fan. Geo-Marine Letters 27, 249-257.

Reeburgh, W.S., 2007. Oceanic methane biogeochemistry. Chem. Rev. 107, 486-513. doi:10.1021/cr050362v

Rossel, P.E., Elvert, M., Ramette, A., Boetius, A., Hinrichs, K.U., 2011. Factors controlling the distribution of anaerobic methanotrophic communities in marine environments: Evidence from intact polar membrane lipids. Geochim. Cosmochim. Acta 75, 164-184. doi:10.1016/j.gca.2010.09.031

Ruffine, L., Donval, J.P., Croguennec, C., Burnard, P., Lu, H., Germain, Y., Legoix, L., Bignon, L., Cagatay, M.N., Marty, B., Madre, D., Pitel-Roudaut, M., Henry, P., Géli, L., 2017. Multiple gas reservoirs are responsible for the gas emissions along the Marmara fault network. Deep-Sea Research Part II: Topical Studies in Oceanography. https://doi.org/10.1016/j.dsr2.2017.11.011.

Ruffine, L., Ondreas, H., Scalabrin, C., Rinnert, E., P., D.J., Croguennec, C., Ponzevera, E., Alix, A.S., Germain, Y., Birot, D., Bignon, L., Etoubleau, J., Teichert, B., Knoery, J., Lesongeur, F., Thomas, B., Roubi, A., Legoix, L., Blanc-Valleron, M.M., Burnard, P., Chevalier, N., Olgunh, K.N., Lu, H., Özaksoyj, V., Perchock, J., Podeur, C., Tarditi, C., Özbekij, E., V, G., Marsset, B., Dupré, S., Fontanier, C., Yang, H., Dissard, D., Chéron, S., Brandily, C., C., C.J., Strauss, H., Pierre, C., Cagatay, M.N., Marty, B., Henry, P., Géli, L., Submitted-b. Multidisciplinary investigation on cold seeps with vigorous gas emissions in the Sea of Marmara (Marsite Cruise): Strategy for site detection and sampling, scientific outcome and research roadmap. Deep-Sea Research Part II: Topical Studies in Oceanography This issue.

Ruffine, L., Germain, Y., Polonia, A., de Prunelé, A., Croguennec, C., Donval, J.-P., Pitel- 
Roudaut, M., Ponzevera, E., Caprais, J.-C., Brandily, C., Grall, C., Bollinger, C., Géli, L., Gasperini, L., 2015. Pore water geochemistry at two seismogenic areas in the Sea of Marmara. Geochem., Geophys. Geosystems 16, 2038-2057. doi:10.1002/2015GC005798.

Skerratt, J. H., Nichols, P. D., Bowman, J. P., Sly, L. I., 1992. Occurrence and significance of long-chain $(\omega-1)$-hydroxy fatty acids in methane-utilizing bacteria. Org. Geochem. 18, 189194.

Stadnitskaia, A., Nadezhkin, D., Abbas, B., Blinova, V., Ivanov, M.K., Sinninghe Damsté, J.S., 2008. Carbonate formation by anaerobic oxidation of methane: Evidence from lipid biomarker and fossil 16S rDNA. Geochim. Cosmochim. Acta 72, 1824-1836. doi:10.1016/j.gca.2008.01.020

Suess, E., 2014. Marine cold seeps and their manifestations: geological control, biogeochemical criteria and environmental conditions. Intern. J. of Earth Sci. 103, 18891916.

Tarutani,T., Clayton, R.N., Mayeda, T.K., 1969. The effect of polymorphism and magnesium substitution on oxygen isotope fractionation between calcium carbonate and water. Geochim. Cosmochim. Acta 33, 987-996.

Thiel, V., Peckmann, J., Seifert, R., Wehrung, P., Reitner, J., Michaelis, W., 1999. Highly isotopically depleted isoprenoids: molecular markers for ancient methane venting. Geochim. Cosmochim. Acta 63, 3959-3966. doi:10.1016/S0016-7037(99)00177-5

Treude, T., Boetius, A., Knittel, K., Wallmann, K., Jørgensen, B.B., 2003. Anaerobic oxidation of methane above gas hydrates at Hydrate Ridge NE Pacific Ocean. Marine Ecological Progress Series 264, 1-14.

Tryon, M.D., Henry, P., Hilton, D.R., 2012. Quantifying submarine fluid seep activity along the North Anatolian Fault Zone in the Sea of Marmara. Mar. Geol., 315-318, 15-28. doi:10.1016/j.margeo.2012.05.004

Tryon, M.D., Henry, P., Cagatay, M.N., Zitter, T.A.C., Géli, L., Gasperini, L., Burnard, P., Bourlange, S., Grall, C., 2010. Pore fluid chemistry of the North Anatolian Fault zone in the Sea of Marmara: A diversity of sources and processes. Geochemistry, Geophys. Geosystems 11, 1-22. doi:10.1029/2010GC003177

Valentine, D.L., Reeburgh, W.S., 2000. New perspectives on anaerobic methane oxidation. Environ. Microbiol. 2, 477-484. doi:10.1046/j.1462-2920.2000.00135.x 
Volkman, J.K. (Ed.), 2006. Marine Organic Matter: Biomarkers, Isotopes and DNA, The Handbook of Environmental Chemistry. Springer-Verlag, Berlin/Heidelberg. doi:10.1007/b11682

Wegener, G., Niemann, H., Elvert, M., Hinrichs, K.-U., Boetius, A., 2008. Assimilation of methane and inorganic carbon by microbial communities mediating the anaerobic oxidation of methane. Environ. Microbiol. 10, 2287-98. doi:10.1111/j.1462-2920.2008.01653.x

Zitter, T.A.C., Henry, P., Aloisi, G., Delaygue, G., Çagatay, M.N., Mercier de Lepinay, B., AlSamir, M., Fornacciari, F., Tesmer, M., Pekdeger, A., Wallmann, K., Lericolais, G., 2008. Cold seeps along the main Marmara Fault in the Sea of Marmara (Turkey). Deep. Res. Part I Oceanogr. Res. Pap. 55, 552-570. doi:10.1016/j.dsr.2008.01.002

\section{Figure captions}

Figure 1. Bathymetric map of the Sea of Marmara showing the tectonic framework and the carbonate crust location (MRS-DV04-CC1). NAF: North Anatolian Fault.

Figure 2. Seafloor pictures from ROV dive MRS-DV595-04. A: general view of Jack the smoker site (white chimney at arrow), B: close-up view of carbonate crust with indication of location of sample MRS-DV04-CC1 (arrow). C: Cross-cut section of the crust MRS-DV04CC1 with the position of the studied subsamples.

Figure 3. Thin section $(3.5 \times 5 \mathrm{~cm})$ of the carbonate crust MRS-DV04-CC1. A: scanned view showing stromatolitic fine laminae molding the lower irregular surface of the crust with two shells of Idas, vacuolar structure of most of the internal part of the crust. B: microscopic view in polarized light showing spheroidal aggregates of aragonite and overgrowths of palissadic aragonitic cement. C: microscopic view in polarized light of bottom of the crust showing spherolitic, micritic, and botryoidal facies of aragonite. D: microscopic view in natural light showing micritic grass-like facies of aragonite and late botryoidal acicular aragonite.

Figure 4. Cross-plot of $\delta^{18} \mathrm{O}-\delta^{13} \mathrm{C}$ values of carbonate subsamples of crust MRS-DV04-CC1. The filled circles correspond to the subsamples from sections; the open circles correspond to the microdrilled subsamples (see Table1). The dashed lines represent the d180 values of aragonite and high-Mg calcite precipitated in isotopic equilibrium with the present-day bottom seawater.

Figure 5. Reconstructed gas chromatograms of the hydrocarbon $(A)$, alcohol $(B)$ and fatty acid (C) fractions extracted from the crust MRS-DV04-CC1 (Tekirdag Basin in the SoM). 
Fatty acids and alcohols were analyzed as their methyl ester and TMS derivatives, respectively. Black circles indicate $n$-alkanes, straight-chain alcohols and saturated fatty acids. IS: internal standards.

Figure 6. SEM photographs (back-scattered imagery) of the crust MRS-DV04-CC1. A \& B: micritic tubular and granular facies of the cream-colored aragonitic layers (longitudinal \& transversal cross sections). C: pyrite-rich layer with isolated crystals and framboids, gastropod mold and foraminifer remains. D: aragonite needles radiating around circular microcrystalline core (10-50 $\mu \mathrm{m}$ of diameter) of spheroidal aggregates. E: pyrite (bright), sulfur (light grey), and secondary gypsum (medium grey) crystals. F: secondary gypsum crystals and pyrite. G: more or less oxidized pyrite associated with aragonite needles. $\mathrm{H}$ : radiating aragonite needles. I: sub-rhomboedral crystals of high-magnesian calcite and aragonite needles, pyrite framboids, nearby biofilm.

Table 1. Mineralogy and isotopic composition of the carbonate crust MRS-DV04-CC1 subsamples.

\begin{tabular}{|c|c|c|c|c|c|c|c|c|c|c|}
\hline $\begin{array}{l}\text { MRS-DV04-01 } \\
\text { subsamples }\end{array}$ & $\begin{array}{c}\text { Total } \\
\text { carbona } \\
\text { te wt } \%\end{array}$ & $\begin{array}{c}\text { Aragoni } \\
\text { te rel } \\
\text { wt\% }\end{array}$ & $\begin{array}{c}\text { Mg- } \\
\text { Calcit } \\
\text { e rel } \\
\text { wt } \%\end{array}$ & $\begin{array}{c}\mathrm{d}_{104} \\
\mathrm{Mg}- \\
\text { Calcit } \\
\mathrm{e}\end{array}$ & $\begin{array}{c}\mathrm{MgC} \\
\mathrm{O}_{3} \\
\text { mole } \\
\%\end{array}$ & Detrital minerals & $\begin{array}{c}\text { Pyrit } \\
\text { e }\end{array}$ & $\begin{array}{c}\text { Accessor } \\
y \\
\text { minerals }\end{array}$ & $\begin{array}{c}\delta^{18} \mathrm{O} \\
\% \circ \\
\text { VPD } \\
B\end{array}$ & $\begin{array}{c}\delta^{13} \mathrm{C} \\
\% \circ \\
\text { VPD } \\
\text { B }\end{array}$ \\
\hline $\begin{array}{l}\text { zone A: dark slightly } \\
\text { cemented }\end{array}$ & 64 & 99 & 1 & 3,000 & 12 & Clay (tr), Quartz? & ++ & $\begin{array}{l}\text { Gypsum } \\
\text { (tr) }\end{array}$ & 1,1 & $-43,0$ \\
\hline zone B: grey & 85 & 89 & 11 & 3,012 & 8 & Clay (tr), Quartz? & $\operatorname{tr}$ & & 0,5 & $-39,5$ \\
\hline zone C: cream-colored & 93 & 96 & 4 & 3,009 & 9 & Clay (tr), Quartz? & $\operatorname{tr}$ & & 0,2 & $-36,3$ \\
\hline zone 1, light grey & 94 & 92 & 8 & 3,011 & 8 & Clay (tr), Quartz? & + & & 0,8 & $-41,9$ \\
\hline zone 1 , darker grey & 88 & 88 & 12 & 3,011 & 8 & $\begin{array}{l}\text { Clay (tr), Fd (?), } \\
\text { Quartz? }\end{array}$ & ++ & & 0,6 & $-42,6$ \\
\hline zone 2, grey and white & 91 & 92 & 8 & 3,011 & 8 & Quartz (tr), Clay (?) & + & & 0,5 & $-39,3$ \\
\hline zone 3, light grey & 93 & 85 & 15 & 3,011 & 8 & Clay (tr), Quartz (tr) & + & & 0,2 & $-38,2$ \\
\hline zone 3 , darker grey & 93 & 77 & 23 & 3,011 & 8 & Clay (tr), Quartz (tr) & + & & 0,3 & $-39,4$ \\
\hline $\begin{array}{l}\text { zone } 3 \text {, lower laminated } \\
\text { part with orange biofilm }\end{array}$ & 90 & 92 & 8 & 3,011 & 8 & Quartz (tr), Clay (?) & + & Sulfur (tr) & 0,7 & $-37,7$ \\
\hline zone 3, grey and white & 94 & 92 & 8 & 3,011 & 8 & Quartz (tr), Clay (?) & + & & 0,6 & $-40,5$ \\
\hline zone 4, grey & 94 & 89 & 11 & 3,011 & 8 & Clay?, Quartz? & + & & $-0,3$ & $-41,0$ \\
\hline zone 4, dark grey granular & 94 & 91 & 9 & 3,012 & 8 & Clay?, Quartz?, Fd? & + & & 0,5 & $-39,6$ \\
\hline zone 5 , border of the crust & 88 & 94 & 6 & 3,010 & 8 & Clay?, Quartz? & + & Sulfur (tr) & 0,6 & $-38,6$ \\
\hline
\end{tabular}




\begin{tabular}{|c|c|c|c|c|c|c|c|c|c|c|}
\hline zone 5, cream-colored & 91 & 95 & 5 & 3,010 & 8 & Clay?, Quartz? & + & & 0,3 & $-37,3$ \\
\hline zone 5 , grey & 95 & 85 & 15 & 3,011 & 8 & Quartz (tr), Clay (?) & + & & $-0,2$ & $-40,6$ \\
\hline micro-sample (1) & - & - & - & - & - & - & - & - & 0,8 & $-41,6$ \\
\hline micro-sample (2) & - & - & - & - & - & - & - & - & 0,4 & $-38,8$ \\
\hline micro-sample (3) & - & - & - & - & - & - & - & - & $-1,5$ & $-39,3$ \\
\hline micro-sample (4) & - & - & - & - & - & - & - & - & 0,0 & $-40,1$ \\
\hline micro-sample (5) & - & - & - & - & - & - & - & - & 0,1 & $-37,6$ \\
\hline micro-sample (6) & - & - & - & - & - & - & - & - & $-0,1$ & $-38,1$ \\
\hline micro-sample (7) & - & - & - & - & - & - & - & - & 0,5 & $-38,8$ \\
\hline micro-sample (8) & - & - & - & - & - & - & & - & 0,6 & $-40,3$ \\
\hline micro-sample (9) & - & - & - & - & - & - & & - & 1,0 & $-41,3$ \\
\hline micro-sample (10) & - & - & - & - & - & - & & - & 0,2 & $-40,2$ \\
\hline micro-sample (11) & - & - & - & - & - & - & - & - & 0,9 & $-39,1$ \\
\hline
\end{tabular}

Table 2. Concentrations and carbon isotopic compositions of archaeal lipids extracted from the carbonate crust MRS-DV04-CC1 subsamples.

\begin{tabular}{|c|c|c|c|c|c|c|c|c|c|c|c|c|}
\hline & \multicolumn{2}{|c|}{ section 1} & \multicolumn{2}{|c|}{ section 1' } & \multicolumn{2}{|c|}{ section 2} & \multicolumn{2}{|c|}{ section 3} & \multicolumn{2}{|c|}{ section 4} & \multicolumn{2}{|c|}{ section 5} \\
\hline & $\begin{array}{c}\mu \mathrm{g} / \mathrm{g} \\
\mathrm{dw}\end{array}$ & $\begin{array}{l}\delta^{13} \mathrm{C} \\
(\%)\end{array}$ & $\begin{array}{c}\mu \mathrm{g} / \mathrm{g} \\
\mathrm{dw}\end{array}$ & $\begin{array}{l}\delta^{13} \mathrm{C} \\
(\% \circ)\end{array}$ & $\begin{array}{l}\mu \mathrm{g} / \mathrm{g} \\
\mathrm{dw}\end{array}$ & $\begin{array}{l}\delta^{13} \mathrm{C} \\
(\%)\end{array}$ & $\begin{array}{c}\mu \mathrm{g} / \mathrm{g} \\
\mathrm{dw}\end{array}$ & $\begin{array}{l}\delta^{13} \mathrm{C} \\
(\%)\end{array}$ & $\begin{array}{c}\mu \mathrm{g} / \mathrm{g} \\
\mathrm{dw}\end{array}$ & $\begin{array}{l}\delta^{13} \mathrm{C} \\
(\%)\end{array}$ & $\begin{array}{c}\mu \mathrm{g} / \mathrm{g} \\
\mathrm{dw}\end{array}$ & $\begin{array}{l}\delta^{13} \mathrm{C} \\
(\%)\end{array}$ \\
\hline Archaeol & 23.8 & -106 & 7.5 & -106 & 36.8 & -105 & 4.9 & -106 & 8.6 & -104 & 6.2 & -105 \\
\hline $\begin{array}{l}S n-2- \\
\text { hydroxyarchaeol }\end{array}$ & 2.6 & -102 & 22.4 & -101 & 0.8 & nd & 2.1 & -101 & 10.4 & -100 & 4.1 & -101 \\
\hline Phytanol & 0.8 & -98 & 0.9 & -97 & 1.8 & -97 & 0.4 & -96 & 0.8 & -96 & 0.6 & -96 \\
\hline Crocetane (Cr:0) & 2.9 & -116 & 3.6 & -113 & 5.0 & -115 & 2.8 & -115 & 3.9 & -114 & 5.2 & -115 \\
\hline Cr: 1 & 0.6 & -113 & 0.7 & -110 & 1.3 & -114 & 0.7 & -113 & 1.0 & -113 & 1.7 & -114 \\
\hline $\mathrm{Cr}: 2$ & 0.2 & nd & 0.1 & nd & 0.4 & nd & 0.4 & nd & 0.5 & nd & 1.1 & nd \\
\hline PMI:2 & 0.9 & nd & 2.1 & nd & 0.9 & -112 & 1.3 & -113 & 1.4 & -113 & 1.9 & nd \\
\hline PMI:3 & 4.4 & -120 & 14.3 & -116 & 8.7 & -118 & 9.0 & -117 & 9.3 & -117 & 10.6 & -117 \\
\hline PMI:4 & 2.6 & -121 & 9.0 & -116 & 4.9 & -121 & 5.6 & -116 & 5.5 & -116 & 6.8 & -116 \\
\hline$\Sigma$ PMIs & 7.9 & & 25.4 & & 14.5 & & 15.9 & & 16.2 & & 19.3 & \\
\hline
\end{tabular}


determined

Table 3. Concentrations and carbon isotopic compositions of bacterial lipids extracted from the carbonate crust MRS-DV04-CC1 subsamples.

\begin{tabular}{|c|c|c|c|c|c|c|c|c|c|c|c|c|}
\hline & \multicolumn{2}{|c|}{ section 1} & \multicolumn{2}{|c|}{ section $1^{\prime}$} & \multicolumn{2}{|c|}{ section 2} & \multicolumn{2}{|c|}{ section 3} & \multicolumn{2}{|c|}{ section 4} & \multicolumn{2}{|c|}{ section 5} \\
\hline & $\begin{array}{c}\mu \mathrm{g} / \mathrm{g} \\
\mathrm{dw}\end{array}$ & $\begin{array}{l}\delta^{13} \mathrm{C} \\
(\%)\end{array}$ & $\begin{array}{c}\mu \mathrm{g} / \mathrm{g} \\
\mathrm{dw}\end{array}$ & $\begin{array}{l}\delta^{13} \mathrm{C} \\
(\%)\end{array}$ & $\begin{array}{c}\mu \mathrm{g} / \mathrm{g} \\
\mathrm{dw}\end{array}$ & $\begin{array}{l}\delta^{13} \mathrm{C} \\
(\% \mathrm{)})\end{array}$ & $\begin{array}{c}\mu \mathrm{g} / \mathrm{g} \\
\mathrm{dw}\end{array}$ & $\begin{array}{l}\delta^{13} \mathrm{C} \\
(\%)\end{array}$ & $\begin{array}{c}\mu \mathrm{g} / \mathrm{g} \\
\mathrm{dw}\end{array}$ & $\begin{array}{l}\delta^{13} \mathrm{C} \\
(\%)\end{array}$ & $\begin{array}{c}\mu \mathrm{g} / \mathrm{g} \\
\mathrm{dw}\end{array}$ & $\begin{array}{l}\delta^{13} \mathrm{C} \\
(\%)\end{array}$ \\
\hline \multicolumn{13}{|l|}{ FAMEs } \\
\hline$n-\mathrm{C}_{14: 0}$ & 3.5 & -68 & 13.7 & -74 & 6.6 & -76 & 4.5 & -72 & 6.8 & nd & 8.0 & -70 \\
\hline$i-\mathrm{C}_{15: 0}$ & 15.9 & -100 & 58.3 & -99 & 38.6 & $\begin{array}{c}- \\
100\end{array}$ & 21.3 & -99 & 38.3 & -99 & 36.3 & -97 \\
\hline$a i-\mathrm{C}_{15: 0}$ & 6.6 & -89 & 33.4 & -97 & 16.0 & -96 & 8.3 & -95 & 12.7 & -93 & 15.5 & -94 \\
\hline$n-\mathrm{C}_{16: 1 \omega 5}$ & 23.9 & -89 & 91.6 & -86 & 45.1 & -89 & 29.8 & -87 & 39.4 & -87 & 55.8 & -87 \\
\hline $\mathrm{C}_{18-\mathrm{OH}}$ & 21.6 & -98 & 159.3 & -97 & 67.2 & $\begin{array}{c}- \\
100\end{array}$ & 26.9 & -98 & 35.6 & -97 & 69.7 & -97 \\
\hline \multicolumn{13}{|l|}{ Alcohols } \\
\hline$n-\mathrm{C}_{14: 0}$ & 0.9 & -76 & 0.9 & -76 & 1.4 & -75 & 0.7 & -74 & 0.6 & -70 & 0.6 & -71 \\
\hline$n-\mathrm{C}_{15: 0}$ & 0.5 & -79 & 0.4 & -79 & 0.5 & -78 & 0.3 & -77 & 0.2 & nd & 0.3 & -81 \\
\hline$n-\mathrm{C}_{16: 1}$ & 3.6 & -80 & 4.3 & -80 & 5.5 & -80 & 3.0 & -80 & 2.2 & -79 & 2.7 & -80 \\
\hline$n-\mathrm{C}_{16: 0}$ & 3.4 & -77 & 3.0 & -77 & 4.6 & -77 & 2.3 & -76 & 1.9 & -72 & 2.4 & -74 \\
\hline$n-\mathrm{C}_{17: 1}$ & 0.5 & -85 & 0.4 & -83 & 0.7 & -81 & 0.3 & -81 & 0.3 & nd & 0.6 & -83 \\
\hline DAGEs (1 and 2) & 8.9 & -90 & 19.7 & -89 & 13.6 & -87 & 10.1 & -87 & 10.5 & -86 & 15.6 & -88 \\
\hline
\end{tabular}




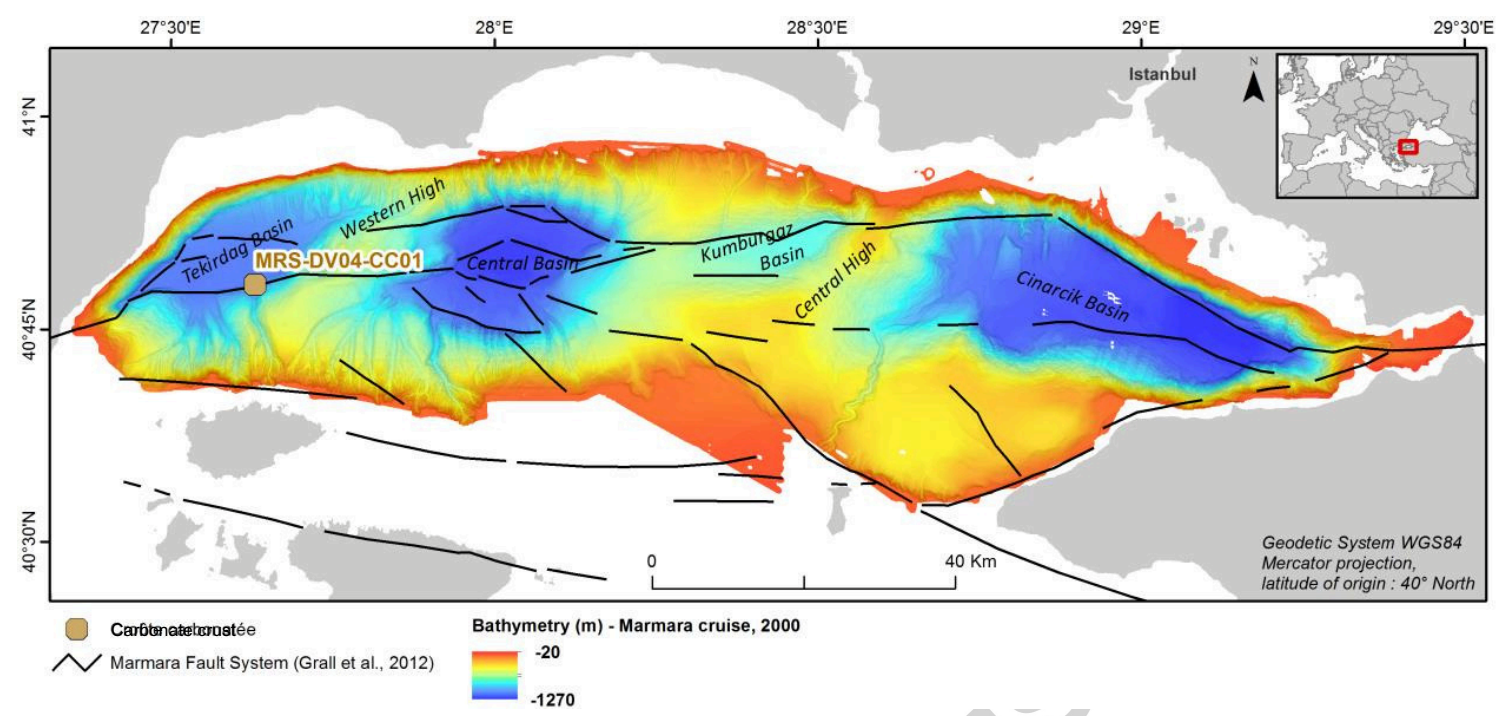

Figure 1

\section{Akhoudas et al.}



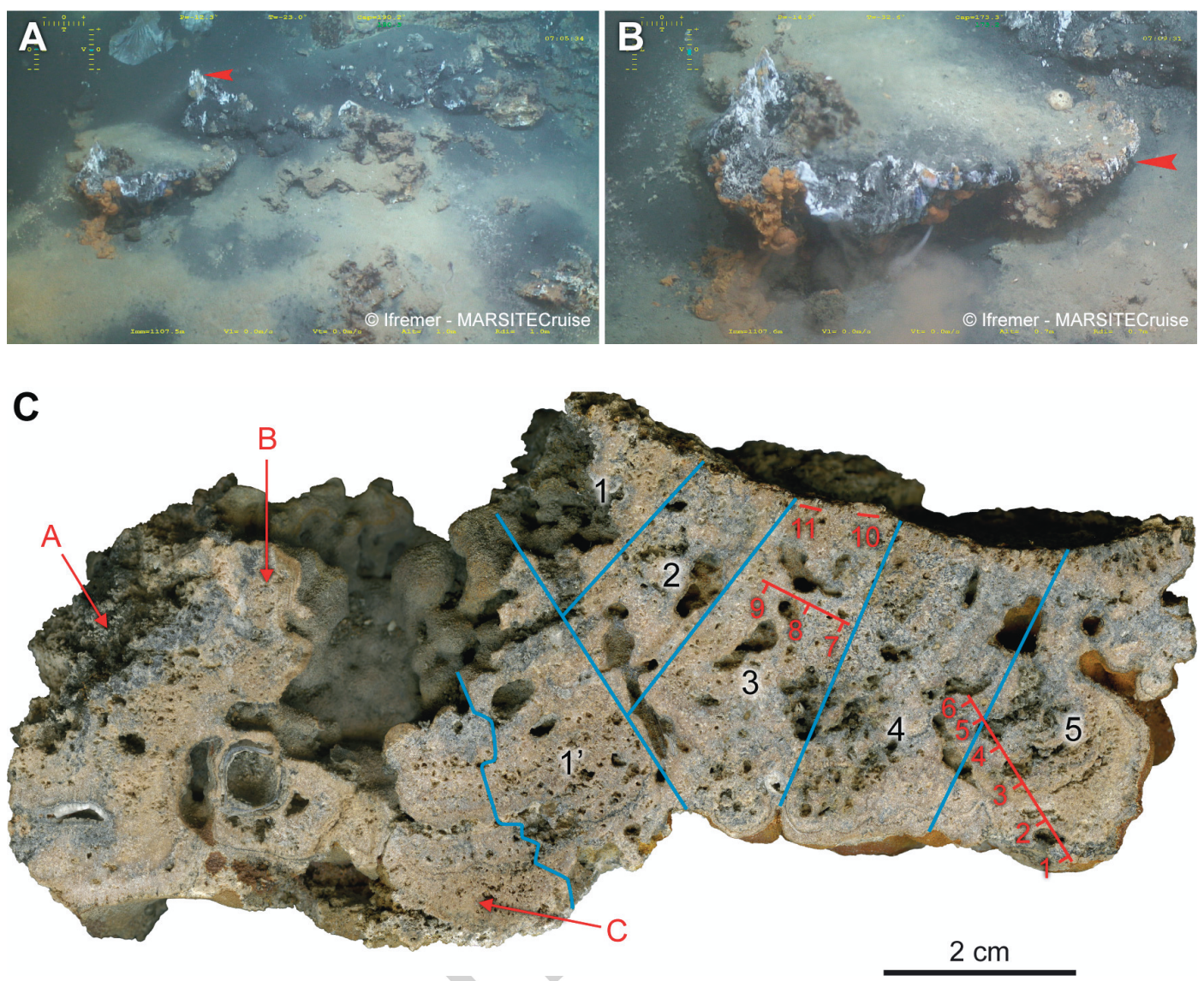

Figure 2

\section{Akhoudas et al.}



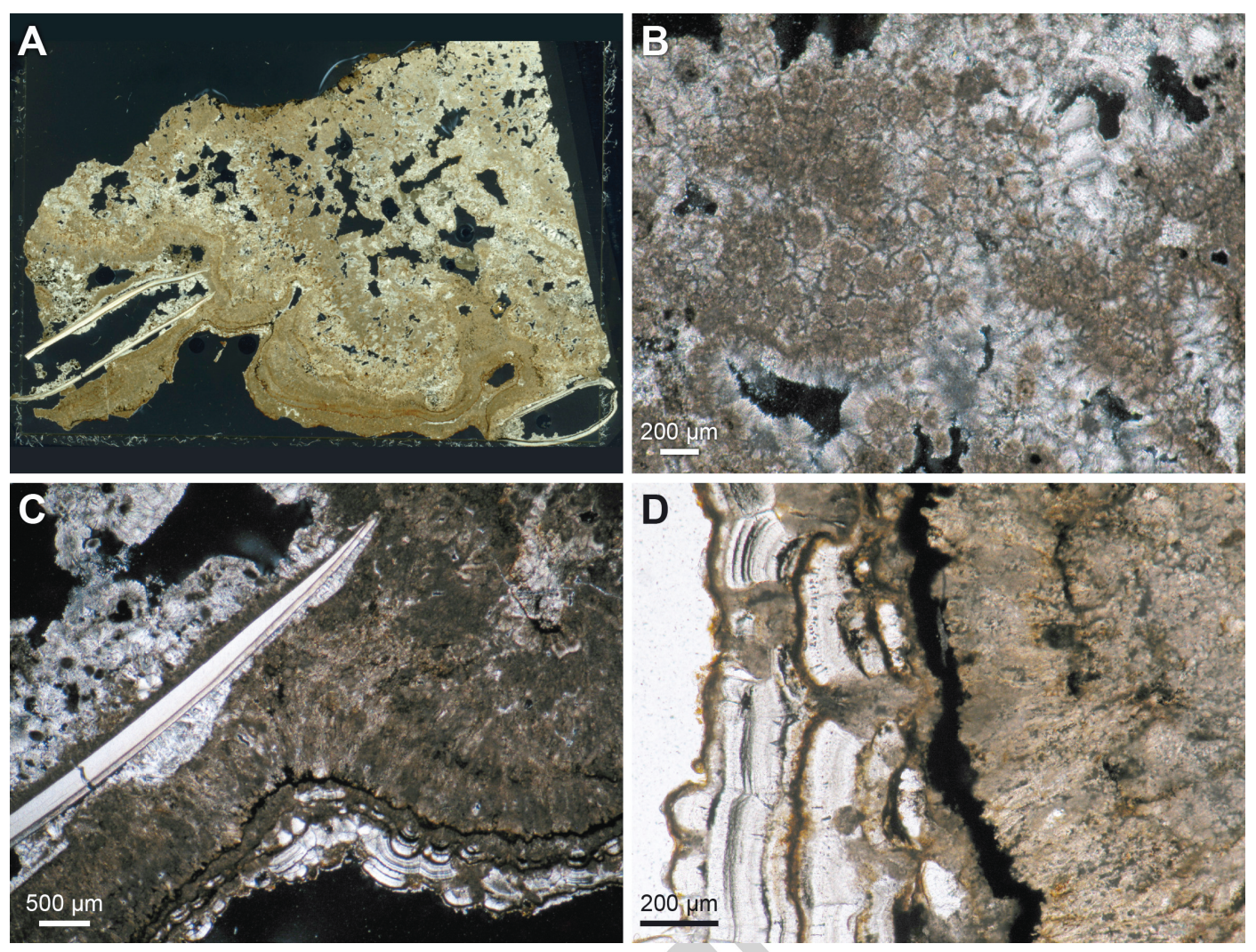

Figure 3

\section{Akhoudas et al.}




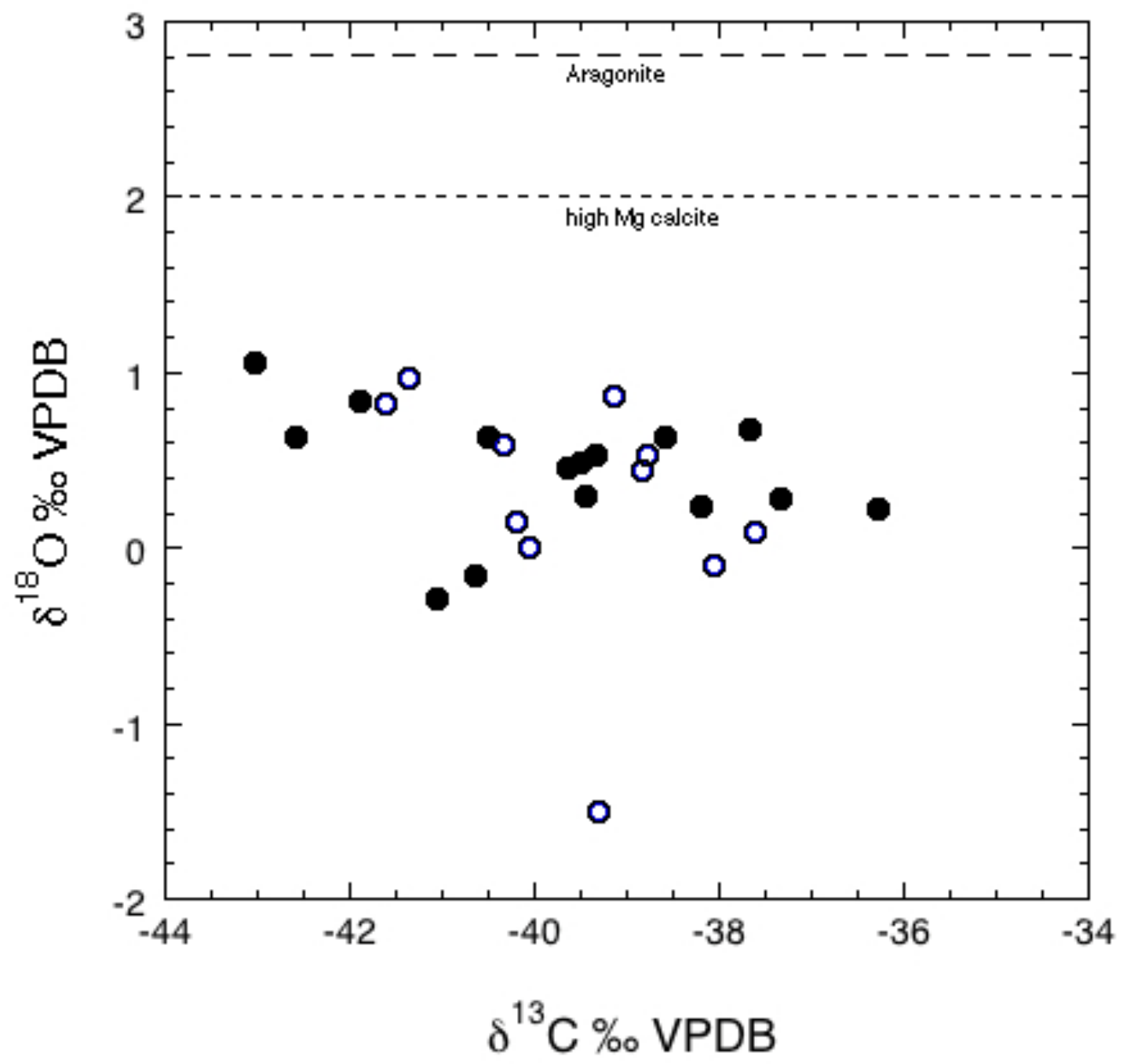

Figure 4

Akhoudas et al. 


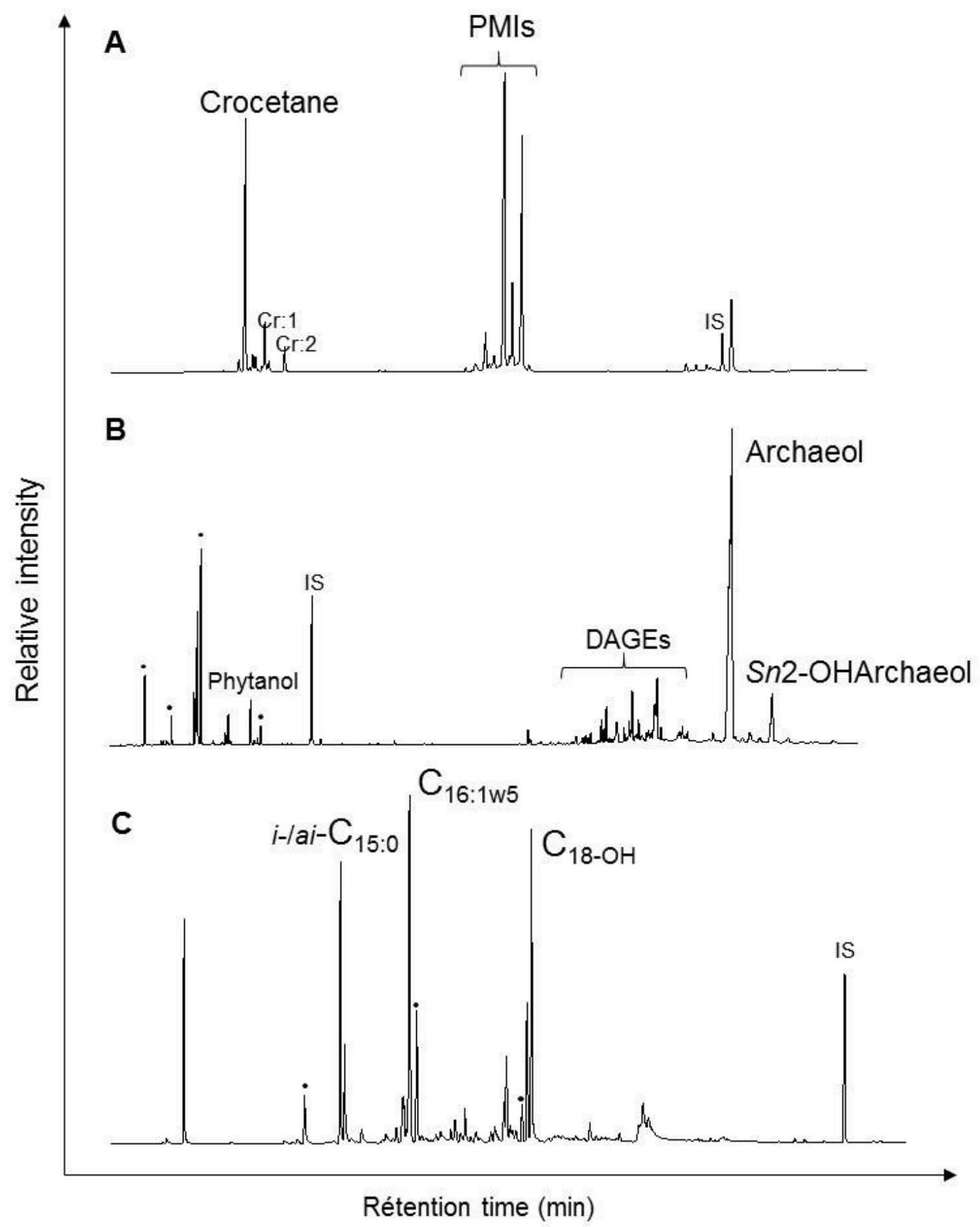

Figure 5

\section{Akhoudas et al.}



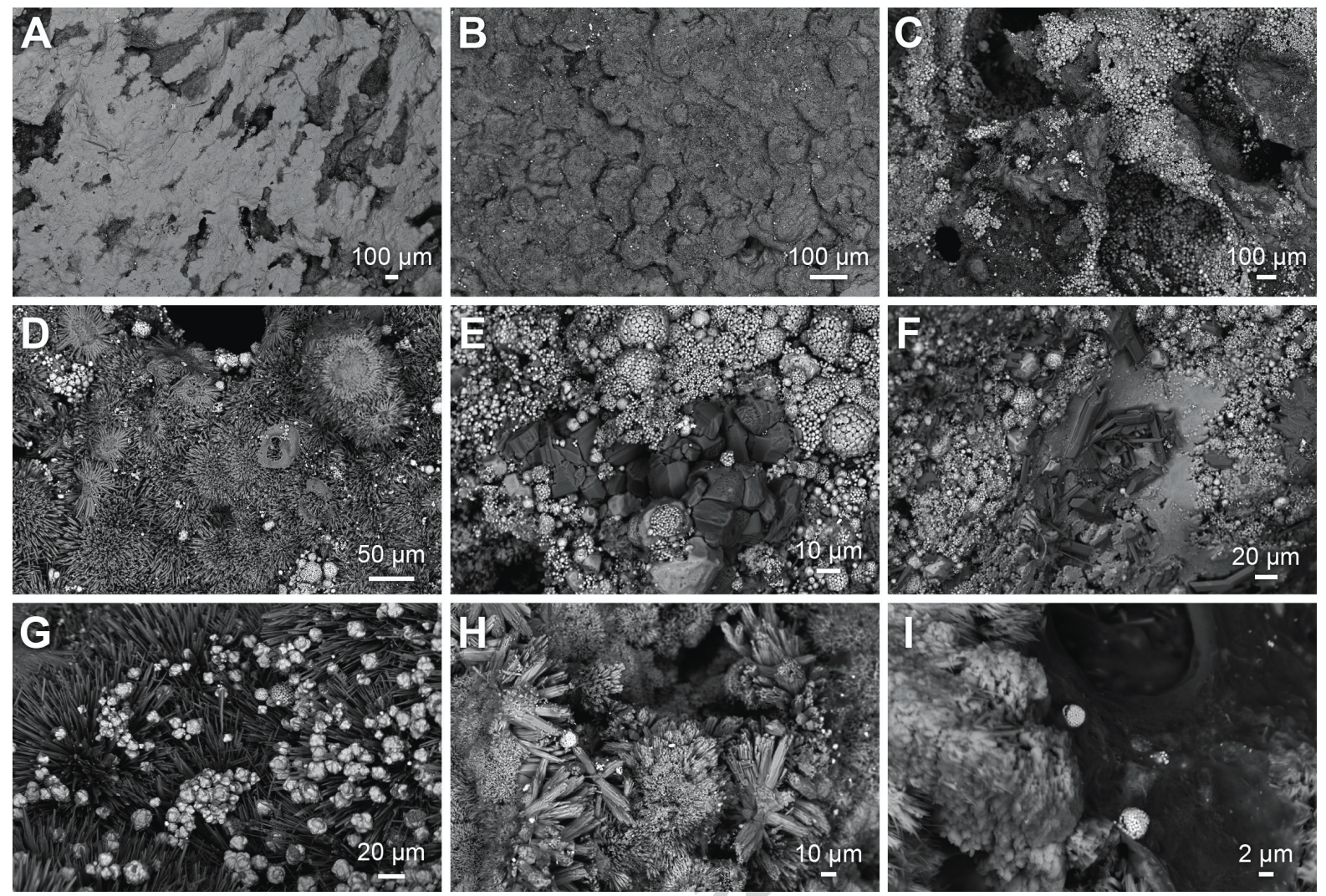

Figure 6

\section{Akhoudas et al.}

